\title{
PLACE AND SIGNIFICANCE OF LATINISMS IN THE SLOVAK VOCABULARY
}

\section{Katarína Karabová ${ }^{1}$}

Department of Classical Languages, Trnava University in Trnava

\author{
Review paper
}

UDC: $811.162 .4 \cdot 373.45: 811.124$

Received: 04.09.2014.

Accepted: 15.09.2014.

\begin{abstract}
Vocabulary of any language undergoes a natural evolution. In many cases this centuries-long process is related to several factors, including the penetration of new words into the language lexis. Similarly, the historical development of the Slovak language and its enhancement can be observed by examining the adoption of words from other languages. At a time when Latin was the only official language as well as the language of scholars and religious institutions in the Hungarian Kingdom, the penetration of Latinisms into the lexis of the old Slovak was significant. This trend was still evident in the 18th and 19th centuries marked by the beginning revivalist efforts. Domestication of adopted words - that initially stood at the edge of the language standard - was significantly influenced by innovative trends and technologies. The study does not primarily examine penetration of foreign words from modern languages, but it aims to analyse the process of naturalisation of Latinisms in Slovak and their use at different language levels.
\end{abstract}

Keywords: latinisms, historical development, Slovak vocabulary, penetration of new words

\section{INTRODUCTION}

Penetration of foreign words into a language in the context of its historical development is not uncommon. It is a natural process of enhancement and enrichment of a language, which is directly related to communication between different language communities. Many words that we now consider as part of the vocabulary, passed into our language from foreign languages (Mistrík, 1995). One of the ways to explore the natural development of the mother tongue is exploring its identity in the meeting point of cultures and characterizing tendencies that are typical for the use of the language in various situations, styles and genres. In connection with the chosen topic, it is necessary to draw attention to the period of pre-codified Slovak language when the greatest amount of foreign vocabulary consisted of
Latinisms. The very Latin in its grammatical system affected the structure of the modern languages and the terminology is still essentially derived from Latin and ancient Greek vocabulary. Latin played a significant role in communication in our territory for several centuries. It is therefore interesting to consider the areas of life that adopted Latin neologisms most frequently. Although Latin was not a national language since the $7^{\text {th }}$ century, it must not be evaluated as a dead language for several subsequent centuries. It became the language of scholars and a language of official communication. Latin was used as a lingua Franca (Juríková, 2011) in Europe until the 19th century. Due to this fact, there are several areas where the penetration of Latin words into Slovak should be noted primarily.

\footnotetext{
${ }^{1}$ Correspodence to:

Correspodence to: Department of Classical Languages, Trnava University in Trnava

Hornopotočná 23, 91843 Trnava, Slovak Republic

E-mail: katarina.karabova@truni.sk
} 


\section{LATINISMS IN THE SLOVAK VOCABULARY}

Besides serving as scholars' communication language, Latin was a language of religious institutions. Such status is still valid today in the Catholic Church, since the Vatican issues all the essential documents, encyclicals and papers in Latin. The fact that Latin was the liturgical language of the Roman Catholic Church provided - by means of the liturgy - space for penetration of Latinisms into the vocabulary of ordinary people who did not speak Latin. This can be seen as one of the facts that to this day the expressions with theological shading such as diakon, kancionál, apoštol, kalvária, testament and others (Kopecká, 2011) are used in Slovakia. Even diverse Slovak dialects contain an increased number of words adopted from Latin. This relates to the already above-mentioned phenomenon of using Latin in the period from the 8 th to the 19 th century. Although ordinary people did not master Latin - at least not to the extent that they would be able to speak fluently - there is a presumption that in certain situations even these people inevitably encountered Latin and it was necessary for them to understand it. Nowadays, however, it is difficult to reconstruct how such communication took place. As indicated above, some adopted words became a natural part of the vocabulary of a language to such extent that today, few people are aware of their foreign origin. Perhaps the best example of such adopted and domesticated words in the Slovak lexicon, which originated in Latin, are the names of the calendar months. Slovak as one of the few Slavic languages adopted these names from Latin. Besides them, there are many completely domesticated words of Latin origin from the Christian terminology, such as: advent, vigília, procesia, breviár, rekviem etc. A special part of the vocabulary adopted from Latin, as suggested, is the terminology associated with different scientific disciplines.

Domestication of a word based on certain historical connotations that somehow herald practical meaning of the word is less frequent. Such is for example a term mecenáš derived from the name of an ancient art patron G. Cilnius Maecenas, who lived during the reign of Emperor Augustus. His name in this sense entered also other European languages. For example mecenášství in Czech, mecenaat in Dutch, Mäzen in German or mecenatismo in Italian. Hereby, let us mention the term "teatrálny". Quite clearly it is an adjective derived from the concept of theatrum that penetrated into Latin from the Greek and means theatre. Although the Slovak lexicon considers teátrum as an obsolete word, or as used in an expressive meaning corresponding to making performance or scenes, the adjective theatrical is used quite commonly with a meaning of feigned, mannered, and focused on the effect. In case of a number of adopted expressions that are already established in the lexicon of the Slovak language, the people rarely realize their Latin origin. A good example of this phenomenon is the word štúdium. Today we can use one word base štud- to create several Slovak words such as študent, študovat', študijný. Today these terms are not perceived by the wider public as words of foreign origin, although they come from the Latin studium, that applied to diligence, effort, as well as occupation, science, art. The similar concept applies to a term author from the Latin auctor, which expressed inter alia, inventor, originator of the idea or work. The word cela is not purely Slovak either. The original Latin term cella means a small dark room. Which of the motorists knows that the word "defekt" was derived from the Latin defectus or defectio implying exhaustion, fatigue, loss? The word "guma", which is - in a sense - related to the previous example, is today hardly associated with its indeclinable counterpart in the Latin gummi, which was the term for resin, tar. Only few people would pause and consider the foreign origin of the word ruina. And yet many centuries ago this word denoted a ruin, wreck. The term pódium, which we use today in connection with a section of the theatre, was used in the ancient times to refer to the balcony in the theatre. To conclude this section, let us mention the term tabul'a, probably the most used object in the school environment or as a solemnly laid table. In ancient times the term tabula was used to refer to denote a plate or a small board for writing, but this term also indicated a table of a money-dealer. In plural it meant a contract, testament or accounts. Several of these already established adopted words serve as synonyms alongside the domestic expressions. At this point it should be mentioned that a similar situation exists even in case of adopted words from other languages. An example here is term fl'ak derived from the German, which is synonymous with the Slovak term škvrna; while the synonym of the Slovak prilba is a word of German origin helma. There are much more similar examples in English, although it must be said that English is the language that has affected the Slovak lexicon especially in recent years. We should not ignore Hungarian, which has a reasonable meaning in the development of the Slovak language with respect to certain historical context. 
Hereby we do not mean words associated with the national culture and customs, such as the term for hot pepper feferónka or čipka for a crochet or a bobbin product with delicate patterns. Today, only few people would derive a daily used word gombík (button) from Hungarian, similarly as koč, papuče, pagáč (carriage, slippers, scone).

However, let us get back to the Latin, from which a large number of words originate that now play a role of full synonyms in the vocabulary. Before listing several examples of this phenomenon, let us briefly note that such a process was not uncommon even in Latin. There are several professional guides from the period neolatin literature, in which the authors deal with issues of enhancement of vocabulary - synonymy (Sipekiová, 2010). A Latin term urna, which in the past served to name a bucket or a container, is nowadays associated mainly with two of its functions. Urn as a repository for the ashes of dead and the election ballot box. It should be noted that in this sense it was also used in ancient times. Similarly sounding words afekt and efekt are also of Latin origin. They come from two verbs with the same word root afficere (act, cause, weaken) and efficere (cause, perform). While afekt is used in association with a loss of self-control, efekt is now synonymous to result, effectiveness. Likewise the word akt derived from supine actum of the Latin verb agere (act, do), which, however, has many meanings, is used in the contemporary Slovak as a synonym to act, deed. The verb agere is also a base for the word akcia in the meaning of an activity, event. The origin of the word advokát should be sought in the Latin verb advocare (call someone for consultation). Today it is used in the legal field to denote a legal counsel. The confiscation of property is linked to the term exekúcia, which also comes from the Latin word exsecutio that applied to the enforcement of the judgment. To contradict an opinion or to oponovat' is derived from the Latin verb opponere, which meant to stand opposite or lie opposite of something. The verb lamentovat' (lament, cry) - although it might seem purely native in the Slovak lexis - comes from Latin, in particular from the word lamentari. Also the word regál denoting a larger shelf with several racks comes from Latin, same as recept, matrika, koruna, mapa, kópia (recipe, registry office, crown, map, copy) and many others. Establishment of foreign words in Slovak is also related to a negative phenomenon, which should not be forgotten. As an example, let us use the adjective optimálny (optimal) that comes from the Latin superlative optimus belonging to graduation of the adjective bonus (good). In Slovak it also means the best, the most favourable. Nevertheless it is often used with improper utilization of its superlative najoptimálnejší (the most optimal). This is an illogical procedure related to ignorance of the true meaning of the word "optimal". Latin superlative optimus also provides the basis for the Slovak word optimistický (optimistic). This term refers to life attitude with a tendency to look at the bright side of things. Although one could think of forming a comparative or superlative even in this case, the terms optimistickejší (more optimistic) and najoptimistickejší (the most optimistic) can be used quite fairly in certain situations. It would be possible to proceed analogically with the term pesimistický (pessimistic), which penetrated into the Slovak vocabulary from the Latin superlative pessimus from the positive malus. In Slovak its meaning is linked to someone who tends to emphasize and see the negative sides of life and generally doubt the favourable development of event.

An interesting survey presents the differences between the meanings of words adopted from Latin in the pre-codification period compared to their current meanings; and the analyses point to the fact that the words adopted from Latin, which were commonly used in the past are no longer in the Slovak vocabulary, or they are considered to be archaisms. While the term artista was used in the past to denote a man who dealt with the production of chemical mixtures, today it is used to denominate circus and a performing artist. Fiškus in the past was a representative of a wider City Council; today it is rather a cunning man, speculator. While our ancestors used the term turbák or turbátor, today a term burič (troublemaker) is more settled.

\section{CONCLUSIONS}

Finally, we shall conclude that Slovak vocabulary formed throughout several centuries comprises a plurality of adopted words from several languages. Certainly one of the most used languages in this respect in the past was Latin, which was mostly conditioned by the fact that for many years it served as an official language, and it was also the language of scholars and religious institutions. The process of word adoption from Latin affected almost every area of human life as we demonstrated in our short analysis. Adoption and domestication of words is often related to larger or smaller shifts in the meaning that may be also seen in the historical development of a language. 
In any case, it must be emphasized that the assimilation of foreign language elements in another language is a complex and lengthy process, which aims to enrich the language and provide space for denomination and determination of new terms that relate to the evolution of the whole society.

\section{REFERENCES}

Juríková, E. (2011). Lingua Latina - Lingua Franca. Latinčina v 18. storočí a stredná Európa. In: Pravne $i$ povijesne odrednice granica srednje i jugoistočne Europe. Osijek: Pravni fakultet u Osijeku, 109-113. Mistrík, J. (1995). Moderná slovenčina. Bratislava: SPN.

Sipekiová, N. (2010). Copia linguae Latinae - pramene jazykovej bohatosti. In: Sambucus 6. Trnava: Filozofická fakulta Trnavskej univerzity v Trnave, 109-114. Kopecká, M., Laliková, T., Ondrejková, R., Skladaná, J. Valentová, I. (2011). Staršia slovenská lexika v medzijazykových vztahoch. Bratislava: VEDA. 